Covered in: ERIH PLUS, CEEOL, Index Copernicus, CrossRef, CrossCheck, J-Gate, Google Scholar, Ideas RePeC, Econpapers, Socionet, KVK, WorldCat.

2018, Volume 6, Issue 2, pages: 74-86 | doi: https://doi.org/10.18662/lumenphs/13

\section{Theoretical Aspects of Globalization Philosophy}

\section{Tudoriţa RĂBIGAN1, Dana STANA ${ }^{2}$}

${ }^{1}$ University of Pitesti, Pitesti, Romania, cora tud@yahoo.com

${ }^{2}$ University of Pitesti, Pitesti, Romania, danastana11@gmail.com

\begin{abstract}
Globalization, as a multidimensional process, raises interest through its scope, in terms of both the topicality of the phenomenon, and the content dimension. The literature in the field reveals contradictory opinions of that manifestation, yet one thing is certain, as far as the effects of globalization are concerned, i.e. once the phenomenon becomes chronic, there appear both winners and losers.

The views and opinions of number of specialists can produce clear arguments relating to the perception of globalization. The present study textually analyzes a few points of view held by the specialists and those interested in the domain of globalization and world economy, whishing assert, in this manner, the critical thinking concerning the phenomenon of globalization.
\end{abstract}

Keywords: Globalization; researcb; world economy; pro/against globalization; philosophy of globalization.

How to cite: Răbigan, T., \& Stana, D. (2018). Theoretical Aspects of Globalization Philosophy. Logos Universality Mentality Education Novelty: Philosophy \& Humanistic Sciences, 6(2), 74-86. https://doi.org/10.18662/lumenphs/13 



\section{Introduction}

Known as a science composed of a set of ideas and ideas that interprets and reflects reality under its most general aspects, philosophy has always played a decisive role in the construction of general conceptions of the world and life. Mankind expected it to provide "enlightenment" and address questions and problems that would improve the lives of individuals. Indirectly, it has enriched both individuals and societies. Although globalization has significantly changed almost every aspect of the world, the fundamental task of philosophy has not changed. Persons who have recently studied or are open to wide-ranging information can recognize that the "public" has received a particularly nuanced message in the era of globalization. Information has been received and received frequently and regularly, from the most secure sources, education, and governance system, which can direct this mass of people to realism and pragmatism.

The ultimate product of philosophy is to be an "enlightenment", an escape from servitude. Obviously, authentic existence becomes the goal of philosophy, overcoming pragmatic consciousness.

If we think of the creative and dramatic impact of philosophy in society, we can reflect on the political revolutions that were undoubtedly inspired by the critical philosophy associated with new ways of thinking about education, religion, society and other existential spheres that transformed the ideas considered to be imaginary in reality.

So, now more than ever, the theme of the philosophy of globalization identifies ideas and theses that address issues tangible to ethnic diversity and oppression and at the same time formulate views on the creation of more tolerant and inclusive societies.

The research undertaken by us, designs, for the main purpose, the investigation of the theoretical aspects related to the issues of pros and cons of globalization identified in the Romanian and international literature. Having "draft" definitions and existing views on the philosophy of globalization, we will submit them to a content analysis in order to form an overview of phenomena followers. With the help of existing theories in literature, we will try to argue that today, as before, philosophy is undertaken as an image of the objective world. The philosophy of globalization is a set of ideas shared by people living in large territories on the planet, ideas that have become largely a reality over the years, with broad prospects in the future and driven (through more global organizations than existing ones). 
By elaborating this paper we aim to contribute to the development of the field of research revealing the phenomenon of the philosophy of globalization as a consequence of the modernization of society as a symbol of the unification of some compact ideas of the inherent ideology.

\section{The history and the concept of globalization}

Our study, including concerns common to many specialists in the globalization process, begins by identifying the outset of globalization, generally recognized worldwide, and they gravitate towards the specialized literature in the country and abroad. In the domestic literature it is assumed that "the 15th century could be considered as being the root of the globalization concept, when modernization has gained contour in terms of separating religion from science, the emergence of capitalism, the formation of states or democratic nations, colonization and individualization"(Diaconu, 2005: 104). The concept of "globalization" has been given multiple meanings, and has been accepted by the majority. By separating the religion from science, places of religion obey, of course, today subject to the legitimacy of the scientific approach, accepting the difference from the religious approach as well as its value. Capitalism has proved that it was not just a simple and spontaneous appearance, but rather replaced the communism which would have seemed an eternity where he had gained ground.

At the beginning of the globalization process, the phenomenon itself was compared to a myth, with a wellspring of controversy, not only between the ordinary people, but especially between academic scholars who were disciples of different schools at the time.

The origins of the term "globalization" are derived from the period of the maximal penetration of the ideas of Karl Marx and the followers of Saint-Simon sociological school (Erhan, 2003: 9). In the opinion of the economic analyst Florin Erhan, after a comprehensive analysis of the literature, mankind had to wait until the end of the 1960s, for the term "globalization" to get the academic endorsement, and to acquire genuinely universal scope. After the fall of the "communist bloc", the fear that ordinary people felt of the effects of globalization has increased exponentially. Some skeptical economic analysts accept the context of globalization, as being related to a possible demonstration of the devastating effects on the current world order, having as arguments the reasons for the outbreak of world military disputes. At the opposite pole, there are also some optimistic economic analysts, who argue that the process of globalization is the unique element that legitimizes the continuation of the 
neoliberal world project. At the other pole, there has appeared the ideology of the new transformations of globalization as a "necessary and sufficient myth", through which politicians and governors educate the citizens of their nation-states and prepare them to meet the changes imposed by the establishment of a global economic market. In our opinion, only those who have not fully understood the meaning, role, effects, and perspectives of globalization are not attracted by the apparently obvious demarches and developments generated by the phenomenon of globalization. We have to think that staying isolated, be it a country of course, is not a perfect solution, it is not a choice that would bring the evolution of humankind to the highest stages, but rather a resignation to the historical cycle. It turned out that we all, as human individuals, are limited in a confined space. Just by calling for unanimous positive thinking and trying to see the positivism of globalization, we can understand that only us unites (globalized) ones will be stronger (a whole, a force).

The term globalization was written for the first time in a dictionary (Webster) only in 1961, and later, in 1989, it was joined by other terms, resulting in expressions such as "globalized markets", "globalized institutions", "globalized ecology", "globalized finances", "globalized lifestyles", "globalized communication", "globalized migration", "globalized laws", "globalized civil society", "globalized events", but the range of these expressions could be far above the ones mentioned here (Scholte, 1998: 52 quoted by Popescu, Bondrea, \& Constantinescu, 2004: 22).

Controversial by its effects, globalization has been, and is, positively supported by some specialists, but is regarded as a phenomenon with negative effects by other specialists. There is a variety of definitions for globalization, but each definition has its own point of views according to its author, who compared the phenomenon described, and so there is no unanimously accepted definition.

In the economics dictionary, globalization is defined as a "modality or system of reception and long-term approach to major contemporary problems, caused by the interaction of multiple processes and economic, technical, political, social, cultural, ecological phenomena, etc., and anticipating their settlement in a broad perspective by the international community" (Dobrotă, 1999: 229). We can notice that the definition does not give a definite opinion in favour of, or against globalization, but it brings to the forefront the constant variable of time, designated by the expression "long term", and the dependent variable, "big contemporary problems", encouraging scientific research specialists, through the content thus structured. The role fully attributed to globalization organizations is particularly difficult, with the main task of solving the most 
delicate international issues that can not be reduced to a single state but are the effect of generating causes worldwide. We are well aware of the global issues related to: the global warming that has led and will lead to major catastrophic effects; foods that circulate almost all over the planet, many of which are a source of frequent serious illness among populations (to remember the genetic modification of many cereals, fruits, vegetables, etc.); migration that represents a global phenomenon of unexpected proportions by its very best specialists; the global water deficit, which will increase as global warming increases; the global effects of atmospheric ozone depletion; the issue of global terrorism that amplifies and maintains the fear and insecurity of the citizen in the world, and many other such issues awaiting resolution.

In his book on the fundamental theorists of globalization, author Andrew Jones paraphrases Stiglitz and states that, "those who criticize globalization too often overlook the benefits of globalization, but the globalists have seen in globalization a process per se, considering that developing countries have to accept it if they want to develop and to be able to fight effectively against poverty"(...) "Unfortunately", Stiglitz claims, "for many, globalization has not brought the promised economic benefits, and has failed to bring stability or protect the environment". "Consequently, globalization is neither good nor bad, but it has tremendous potential to do much good, though, for some, this means that it is rather capable of causing an absolute disaster" (Jones, 2011: 189). Although the definition is based on arguments, both for and against globalization, nevertheless, the balance is tipped in favour of the pro-globalization arguments, by the imperative recommendation to developing countries to accept the phenomenon of globalization. The critics of globalization have of course pointed out both the positive and the negative effects, but we believe in increasing the confidence in the forces of the organizations of the globalization process, and we believe that it would be necessary to increase their number in order to increase the effort to solve most problems this nature. The more professionals are involved in solving global problems, the more they will find the solutions if not to solve at least to improve.

The Romanian economic analyst Florin Erhan defined globalization as "the multitude of the economic and social transformations experienced by mankind at present, extended on an integrative scale and generated by the impact of the transcontinental financial and money flows on the characteristics of the social interactions" (Erhan, 2003: 9). The process of globalization is brought by the author up to the present time. His explanations, in the paper dedicated to globalization, are meant to explain facts and manifestations that demonstrate adherence of some followers, and also of some adversaries, to the globalizing process. If we extrapolate the economic and social transformations debated by the author mentioned above, we can see that they are only a part of a colossal 
whole, and the sphere of the transformations of globalization is much more diversified and broader, therefore it is almost impossible to have an exhaustive debate on the process of globalization. Most critics have chosen to identify limited dimensions of globalization and to analyze, investigate problems with the proposed dimensions. A phenomenon that almost entirely covered the life and human existence of the Earth, with only a few exceptions, certainly can only be investigated on dimensions, components or other issues related to the process itself.

According to such prestigious economists as Lucian Anghel and Mihaela Dinu "the modern term is currently used to describe the evolution of society and the economy characterized mainly by increased cooperation between countries, through the intensification of trade, of free capital movements and labor, as well as increased cultural exchanges and the emergence of a true global civil society" (Anghel \& Dinu, 2014: 15). The last words of the definition, i.e. "true global civil societies", suggest the authors' position in favour of the phenomenon of globalization. Seen as something certain, globalization must be accepted by every individual, it must be understood, it needs good information as to its effects, in order for us to adapt and enjoy its positive effects. From our point of view, modernization and evolution, in general, are the result of the globalization process. How about the current man's life without his mobile phone or without the internet?! The two conquests of technology and science alike, through the joint effort of globalizing, are today indispensable like as a man can not live without water or food (without straightening the comparison to exaggeration).

Professor of Sociology and Communication Sciences Paul Dobrescu draws attention by defining globalization as "not a process of modernization with equal benefits for the whole planet", but rather "it leads to the assertion of new powers of the moment, for the countries that have succeeded in defining long-term development strategies and strategies of capitalizing on this complex process" (Dobrescu, 2010: 2425). The definition is likely to be interpreted, arising the interest of the researcher or the mere reader, towards a global analysis of the countries of the planet, in an attempt to better understand which of them have benefited or can benefit from the positive effects of globalization. As a result, we are surprised by a utopia, proven by the fact that there are three categories of countries on the planet: advanced, developing (emerging) and poor, with an effort to strengthen the reduction of substantial disparities between the three categories. The smaller the differences between them, the more players in the planet will take advantage of.

The philosopher Antonio Sandu (2009: 91) states that the contemporary global society is in a period of paradigmatic transition from postmodernism to transmodernism. 
The models proposed by various specialists are quite numerous, some only concern some dimensions of globalization, others try to encompass as much as possible, but it is certain that the paradigms with the most benefits to the planet's population must be implemented. The patterns followed in the practice of globalization on each segment should include the entire population of the planet, but with differentiated approaches.

The famous Hungarian-born American billionaire, economist and businessman George Soros, argues, in a paper dedicated to globalization, that "globalization represents the free movement of capital accompanied by the increasing domination of global financial markets and multinational corporations on national economies" (Soros, 2002: 15). George Soros is preeminently a great advocate of globalization: he is one of the world-famous figures who have benefited, and continue to benefit from the positive effects of globalization. An exponent of the example of those who knew how to adapt, and managed to understand how to benefit from globalization, Soros supports, by his definition, the free movement of capital, especially that of the global financial markets, which helped him become famous in the 1990s. Unite through absolutely everything, including thinking, we are not mistaken to say that we will be the strongest in the struggle with time, which, in our opinion, would be the real and irreplaceable problem for all. The time constant is a real human problem through the aging effect of man and the material world, respectively. Why solve problems related to the effects of some negative thoughts, when the best and most productive would be to look for solutions to the problems of the Universe, of which our planet is part of the whole?!

American literary critic Fredric Jameson (1998: 16, as cited by Cooppan, 2001), philosophizing on globalization, defines it as a cultural process, and considers that "as cultural process, globalization names the explosion of a plurality of mutually intersecting, individually syncretic, local differences; the emergence of new, hitherto suppressed identities; and the expansion of a world-wide media and technology culture with the promise of popular democratization. As economic process... the assimilation or integration of markets, of labor, of nations." As a result, the motto of unity in diversity may be another way to reformulate the definition, and we fully agree with the idea of expanding culture and technology, considering the expansion of the Internet and IT culture. From an economic point of view, we can add a liberalization of all economic components that tend to unify and cover all the shortcomings in the field.

British sociologist Anthony Giddens (1998: 30-31), formulates in his work opinions on the renewal of democracy, a definition that goes beyond the limits of the economy and wishes to entrust globalization, new natural dimensions such as time and space, and states that: "Globalization, as I shall 
conceive of it in what follows, at any rate, is not only, or even primarily, about economic interdependence, but about the transformation of time and space in our lives." It is the same wave of hope that we, too, give ourselves to what can be done inside the globalization, and we consider that we are not going beyond the reality through the unpredictable or just imagined dimensions of the globalization process. Natural phenomena (like the South Asian tsunami produced years ago) tilted the planet's axis and the result seems to have even affected the time. It is only an example that can confirm the transformation of time. Geographically, space becomes the subject of debate and raises issues that need to be resolved, sometimes locally, but often global. Recently, the discovery of the eighth continent, which can not be geographically certified, due to the organizational void in this respect.

Indian librarian Avinash Jha (2000: 3) joins those who are attracting research into the phenomenon of globalization and builds a definition "...integration of national economies leading to the notion of a borderless global or planetary economy... an interwoven net of factories, fields and forests, banks, governments, labouring and farming populations, cities and transport spread over the surface of earth." A moving world, "without frontiers," as Jha says, can only be the dream of an adept of the described phenomenon that allows us to understand even more than globalization, perhaps mondialisation.

In order to support our proposed thesis, we are entering a new stage of research and we are considering a content analysis of the views of globalization specialists, an analysis that will help us to argue the contribution we want to develop in the field of research and enrich the theory of the philosophy of globalization with our new thesis.

\section{Textual analysis of assertions and definitions of globalist specialists}

Using as a „draft" the opinions and the definitions of the authors mentioned in our study, we will resort to a textual analysis to identify the pro and con views on globalization.

Table 1 Opinions pro and against globalization

\begin{tabular}{|l|l|l|}
\hline \multicolumn{1}{|c|}{$\begin{array}{c}\text { Author/ } \\
\text { authors }\end{array}$} & $\begin{array}{c}\text { Points of view } \\
\text { pro/against } \\
\text { globalization }\end{array}$ & \multicolumn{1}{c|}{ Arguments in the text } \\
\hline $\begin{array}{l}\text { Jones } \\
\text { quoted on } \\
\begin{array}{l}\text { Stiglitz 2011: } \\
189)\end{array}\end{array}$ & $\begin{array}{l}\text { On the whole, is } \\
\text { understood a point of } \\
\text { view for-globalization. }\end{array}$ & $\begin{array}{l}\text { "Therefore globalization is neither good nor } \\
\text { bad, but it has a tremendous potential to do a } \\
\text { great well ... " }\end{array}$ \\
\hline
\end{tabular}




\begin{tabular}{|c|c|c|}
\hline $\begin{array}{l}\text { (Erhan, } \\
\text { 2003) }\end{array}$ & $\begin{array}{l}\text { The author advocates } \\
\text { pro-globalization. }\end{array}$ & $\begin{array}{l}\text { Title of the book: } \\
\text { "Globalization in the search for the } \\
\text { equilibrium" }\end{array}$ \\
\hline $\begin{array}{l}\text { (Anghel \& } \\
\text { Dinu 2014: } \\
\text { 15) }\end{array}$ & $\begin{array}{l}\text { The authors have points } \\
\text { of view, pro-globalization. }\end{array}$ & $\begin{array}{l}\text { The last words of the definition of } \\
\text { "true global civil societies" suggest a } \\
\text { favorable position of the authors on the } \\
\text { phenomenon of globalization. }\end{array}$ \\
\hline $\begin{array}{l}\text { (Dobrescu } \\
\text { 2010: 24-25) }\end{array}$ & $\begin{array}{l}\text { On the whole, the } \\
\text { definition has a tinge } \\
\text { against globalization. }\end{array}$ & $\begin{array}{l}\text { "... not a modernization process with equal } \\
\text { benefits for the whole planet ..." }\end{array}$ \\
\hline $\begin{array}{l}\text { (Soros 2002: } \\
15)\end{array}$ & $\begin{array}{l}\text { An important exponent } \\
\text { pro-globalization. }\end{array}$ & $\begin{array}{l}\text { "globalization represent the free motion of } \\
\text { capital ..." }\end{array}$ \\
\hline $\begin{array}{l}\text { (Jameson } \\
\text { 1998: } 16, \text { as } \\
\text { cited by } \\
\text { Cooppan, } \\
\text { 2001) }\end{array}$ & $\begin{array}{l}\text { A positive position towards } \\
\text { the globalization } \\
\text { process. }\end{array}$ & $\begin{array}{l}\text { "As cultural process, globalization names the } \\
\text { explosion of a plurality of mutually } \\
\text { intersecting, individually syncretic, local } \\
\text { differences; the emergence of new, hitherto } \\
\text { suppressed identities; and the expansion of a } \\
\text { world-wide media and technology culture with } \\
\text { the promise of popular democratization. As } \\
\text { economic process...the assimilation or } \\
\text { integration of markets, of labor, of nations." }\end{array}$ \\
\hline $\begin{array}{l}\text { (Bernard, } \\
\text { 2006) }\end{array}$ & Pro globalization & $\begin{array}{l}\text { "The world of privatized globalization and } \\
\text { shared globalization: this is the object of } \\
\text { improbable, and yet philosophical, thinking } \\
\text { that would be that of a "philosophy of } \\
\text { globalization" - from which we now wish to cut } \\
\text { off the quotation marks that accompany it". }\end{array}$ \\
\hline $\begin{array}{l}\text { (Giddens, } \\
\text { 1998: 30-31) }\end{array}$ & $\begin{array}{l}\text { Turns on an optimistic } \\
\text { flame in hopes of } \\
\text { globalization. }\end{array}$ & $\begin{array}{l}\text { "Globalization, as I shall conceive of it in } \\
\text { what follows, at any rate, is not only, or even } \\
\text { primarily, about economic interdependence, but } \\
\text { about the transformation of time and space in } \\
\text { our lives." }\end{array}$ \\
\hline $\begin{array}{l}\text { (Giddens, } \\
\text { 1990: 64) }\end{array}$ & $\begin{array}{l}\text { An opinion that allows } \\
\text { interpretation }\end{array}$ & $\begin{array}{l}\text { "Globalization can thus be defined as the } \\
\text { intensification of worldwide social relations } \\
\text { which link distant localities in such a way that } \\
\text { local happenings are shaped by events occurring } \\
\text { many miles away and vice versa." }\end{array}$ \\
\hline $\begin{array}{l}\text { (Jha, 2000: } \\
\text { 3) }\end{array}$ & $\begin{array}{l}\text { Denotes a positive hope } \\
\text { of the Indian author }\end{array}$ & $\begin{array}{l}\text { "... integration of national economies leading } \\
\text { to the notion of a borderless global or planetary } \\
\text { economy... an interwoven net of factories, } \\
\text { fields and forests, banks, governments, } \\
\text { labouring and farming populations, cities and } \\
\text { transport spread over the surface of earth." }\end{array}$ \\
\hline
\end{tabular}




\begin{tabular}{|l|l|l|}
\hline $\begin{array}{l}\text { (Masala, } \\
\text { 2016: 160) }\end{array}$ & $\begin{array}{l}\text { A thinking against } \\
\text { globalization }\end{array}$ & $\begin{array}{l}\text { Getting into disarray. "Disarray" means } \\
\text { unscrupulousness, lack of transparency, } \\
\text { surprise, and above all, impossibility to plan }\end{array}$ \\
\hline
\end{tabular}

Source: realized by authors

Analyzing the texts in Table 1 , one can easily see that they are generally pro-globalization views, with one exception where globalization is considered a process with unequal benefits for the entire planet.

Looking back over time, industry and agriculture have diminished and redimensioned their place by being replaced by technology, innovation, knowledge. A new hierarchy of values in rural economic development, for example, shows the diminution of national traditions in favor of the new ethical and moral norms, and not a bipolarity from which to emerge the result of globalization.

By making a diagnosis we can see that the philosophy of globalization can not be done without economics, as it is not done without the help of other fields. Moreover, the subject of the current approach is based on the idea of globalization using the economic equilibrium but we ask that there is a single economic thinking in which no areas are trained so that the economy emerges from the current emergence of disorder in this globalized society?

Economy has been a beginning, but it is not a guarantee of the goal of globalization. Each domain needs its own identity to ensure rationalization but only together tested as a system.

On the philosophy of globalization, we can also look at things in a dialectic way, not to take the knowledge of the ideas of others as a definitive and immutable whole, but to analyze how globalization emerges from disunity and globalization as a partial system to see it as a complete and secure part. Thus, the term globalization is often confused with globalization and sometimes with internationalization, but admittedly, differences in content are admitted (Bernard, 2006). In some branches or economic-socio-political processes globally through globalization or globalization is meant partial or almost total integration.

Therefore, the philosophy of globalization will be expanded by examining a number of issues stemming from the human rights principle, summarized in the table below. 
Table 2 Pro and against of globalization from human rights of point of view

\begin{tabular}{|c|c|c|}
\hline $\begin{array}{c}\text { Principles of } \\
\text { getting } \\
\text { legitimacy }\end{array}$ & Positive consequences & Negative consequences \\
\hline Human rights & $\begin{array}{l}\text { - reducing costs and } \\
\text { increasing } \\
\text { competitiveness; } \\
\text { - tax reduction; } \\
\text { - reducing work } \\
\text { conflicts; } \\
\text { - free movement of } \\
\text { capital and partly, a } \\
\text { labor force. }\end{array}$ & $\begin{array}{l}\text { - increasing the role of } \\
\text { transnational institutions in internal } \\
\text { decisions; } \\
\text { - reducing opportunities to } \\
\text { promote and protect internal } \\
\text { interests; } \\
\text { - disadvantages poor states in the } \\
\text { global redistribution of resources } \\
\text { and well-being. }\end{array}$ \\
\hline
\end{tabular}

Source: (Preda, 2007: 198)

From Table 2 we can conclude that the phenomenon of globalization brings only benefits. A poor country (though this is an ambiguous notion, because there are other social problems besides poverty) cannot afford to isolate itself in a protectionist manner, and welfare comes together with the responsabilitation of individuals. In addition, there is not world competitiveness.

On the other hand, if we think of Asian women in India, how they have gained their independence in society, we can only think that they can be political actors, who cannot oppose the traditional marital and gender standards. This aspect, combined with their declared effacement from the system, can support the theory about world systems of migration, their integration into the public space. Here is an example of globalization that changes the gender regime, a positive and liberating postmodern act, yet a negative and undemocratic one at the same time.

\section{Instead of conclusions}

Today, globalization can only be said to be a diachronic concept, since the systemic approach becomes an alternative to the new international order, proposes even a new global model of development: altermondialism. At the moment, alter- mondialism is an ideological model at the stage of proposition, an utopian contest (Duțu, 2006). We could now point out that the philosophy of globalization is itself an ideological concept itself.

The views of the specialists, who are partisans of our thesis, show their national culture as an expression of their traditional spirit, their identity as the people they represent, and the common approach to ideas as an 
intersection of cultures and civilizations, a unique product. Only the question remains whether philosophy in this approach becomes or not refractory to specific contextualizations.

In a one-direction manner, globalization has created an expanded economic system, giving rise to the so-called world economy. Because the homogenization of cultures does not take into account universalism, but only tends to appreciate the orientation towards pluralism, we cannot speak of a unilateral globalization. We can also notice peculiarities of detail.

Examining globalization over time, seen from a cultural point of view, we can note that it corresponded to an expansion of Western lifestyles and values, but one cannot really specify that a certain direction was assigned to it.

From a political point of view, "the ever-new national organizations" (Enciclopedie..., 2007: 398), the migratory population and the personalities in the sphere of religious belief had left a mark on globalization.

Viewed as a whole, the phenomenon of globalization is a hybrid process, a movement of aggregation of forms in contemporary civilization, without however removing the previous ones. We are thus faced with the typical antinomies: universalism and peculiarities, homogenization and differentiation, integration and fragmentation, centralization and decentralization.

The constructive model of global development is long and closely supervised, and negotiation of interpretation comes from all spheres of knowledge as something natural. Accepting almost unanimously this process involves the evolution of a utopian world. Anti-globalization see the destruction of the culture of less developed countries. This is briefly the conclusion drawn from the definitions and opinions of those who have debated the subject of globalization, and we, in contrast to the ones outlined, are contributing to the development of the field under the research of the compact ideas of the authors mentioned as parts of an ideology. The effects of globalization derive from inequalities in this ideological communion, but the meaning is assured. The philosophy of globalization is certainly a consequence of the continuous modernization of society.

\section{References}

Anghel, L. C., \& Dinu, M. (2014). Globalizarea afacerilor [Globalization of business]. Bucharest, Romania: Tritonic.

Bernard, F. (2006). Philosophie des mondialisations et mondialisation de la philosophie [Philosophy of globalization and globalization of philosophy]. Retrieved 
from

http://www.mondialisations.org/php/public/art.php?id=23649\&lan=FR

Diaconu, S. (2005). Progres şi globalizare [Progress and globalization]. In Amfiteatru economic, 7(17), 103-108.

Dobrescu, P. (2010). Viclenia globalizării. Asaltul asupra puterii americane [The cunningly of the globalization. The assault on American power]. Iaşi, Romania: Institutul European.

Dobrotă, N. (Coord.). (1999). Dicționar de economie [Economics Dictionary]. Bucharest, Romania: Economic.

Duțu, M. (2006). Spre un model de globalizare-perspectivele altermondialismului. [Towards a model of globalization - the perspective of altermandalism]. Retrieved from https://www.researchgate.net/publication/237567577_Spre_un_nou_mod el de globalizare - perspectivele altermondialismului

Erhan, F. (2003). Globalizarea în căutarea echilibrului [Globalization in the search for the equilibrium]. Bucharest, Romania: Economic.

Giddens, A. (1990). The Consequences of Modernity. Cambridge, UK: Polity Press.

Giddens, A. (1998). The third way, the renewal of democracy. Cambridge, UK: Polity Press.

Cooppan, V. (2001). World literature and global theory: Comparative literature for the new millennium. Symploke, 9(1-2), 15-43.

Jha, A. (2000). Background to globalisation. Bombay, India: Center for Education and Documentation

Jones, A. (2011). Globalizarea. Teoreticieni fundamentali [Globalization. Theoreticians fundamental]. Cluj-Napoca, Romania: CA Publishing.

Masala, C. (2016). Welt-unordnung. Die globalen kerisen und das versagen des westens [World disorder. The global crises and the failure of the West]. München, Germany: C.H. Beck.

Popescu, A. I., Bondrea A. A., \& Constantinescu I. M. (2004). Globalizarea: mit si realitate [Globalization: myth and reality]. Bucharest, Romania: Economic.

Preda, M. (2007). Politica socială românească între sărăcie şi globalizare [The Romanian social policy between poverty and globalization]. Iaşi, Romania: Polirom.

Sandu, A. (2009). Dimensiuni etice ale comunicării în postmodernitate [Ethical dimensions of postmodern communication]. Iaşi, Romania: Lumen.

Scholte, J. A. (1998). Globalization and social change. Bruxelles, Belgium: Transnational Associations.

Soros, G. (2002). Despre globalizare [About globalization]. Iaşi, Romania: Polirom.

*** Enciclopedie de filosofie si stiințe umane [Encyclopedia of philosophy and human sciences]. (2007). Bucharest, Romania: All Educational. 